\title{
Seasonal variations in physiological response and heat tolerance indices of Sahiwal, HF x Sahwial crossbred and Hill (Badri) Cattle under farm conditions of Uttarakhand
}

\author{
Raoof Ahmad Patoo, Devi Vrath Singh, Prawaz Ahmad Dar, Anees Ahmad Shah, Sheikh Adil and Suheela Nazir
}

Received: 05 September 2018 / Accepted: 12 December 2018 / Published online: 21 February 2019

(C) Indian Dairy Association (India) 2019

\begin{abstract}
Present investigation was conducted on Sahiwal, crossbred (Sahiwal x Holstein Friesian) and Hill (Badri) cattle to study the effect of season on physiological response and heat tolerance indices under farm condition in foot hills of Uttarakhand. Physiological responses of eighteen primiparous lactating cows (four in each group) were recorded daily in morning $(9: 00 \mathrm{am})$ and evening $(3: 00 \mathrm{pm})$ for 20 days in summer, rainy and winter season. Heat tolerance indices like Temperature humidity index, Iberia heat tolerance coefficient, Benezara coefficient of adaptability and Dairy search index were calculated. There was a significant $(\mathrm{P} \leq 0.05)$ difference between mean morning and evening rectal temperature (RT), respiration (RR) and pulse rate (PR) between indigenous and crossbred cows during summer and rainy season. Also significant $(\mathrm{P} \leq 0.05)$ difference was found between winter vs. summer/ rainy season with respect to morning and evening RT, RR and PR in all the groups. Crossbred cows had increased $\mathrm{RT}, \mathrm{RR}$ and $\mathrm{PR}$ than indigenous cattle in all the season. In winter all physiological parameters were significantly $(\mathrm{P} \leq 0.05)$ lower than summer/ rainy season in all the groups. Heat tolerance indices indicated that Sahiwal cows were more heat resistant than Hill (Badri) cows and crossbred cows, the least heat resistant during summer and rainy season. Moreover, during winter season none of the groups were under climatic stress. Study indicated that
\end{abstract}

Raoof Ahmad Patoo $(\square)$
Department of Livestock Production Management, FVSc \& AH
SKUAST-Kashmir 190 006, India
E-mail: raoofpattoo@gmail.com

Devi Vrath Singh, Prawaz Ahmad Dar, Anees Ahmad Shah, Sheikh Adil and Suheela Nazir

Department of Livestock Production Management College of Veterinary and Animal Sciences, GBPUAT Pantnagar, Uttarakhand, 263145 India indigenous breeds were more adaptive to the stressful climatic condition in foot hills of Uttarakhand.

Keywords: Crossbred, Heat tolerance indices, Physiological, Seasonal, Sahiwal, Hill (Badri) cattle, Uttarakhand

Livestock rearing is an integral part of Indian agriculture, which has enormous potential to improve the socio-economic status of large percentage of rural population. It is also an important economic activity in the hilly and mountainous regions, where majority of hill farmers are small holders and they depend on the diversification of agriculture to reduce risks and derive economic benefits from the limited resources they possess. A survey revealed that there is large number of hill (Badri) cattle in Uttarakhand (more than $99 \%$ in hill districts) and are reared mainly on extensive system of management i.e. grazing from morning to evening and managed mostly by ladies. Animals of different farmers are pooled in a group of $25-50$ animals, for grazing in the hilly terrain nearer to water source. The climate of the state varies from subtropical in the plane region to temperate on higher slopes with three distant seasons i.e. summer, rainy and winter. Maximum temperature ranges from 42 to $43^{\circ} \mathrm{C}$ during summers and the minimum temperature varies from 1 to $4^{\circ} \mathrm{C}$ in winter season (Pundir et al., 2013; Patoo et al., 2016b).

Cattle, as other homeothermic animals, require relatively constant core body temperature for their vital and productive processes. An ambient temperature of $30^{\circ} \mathrm{C}$ seems to be the critical temperature at which Bos taurus and Bos indicus begin to differ in their ability to maintain near normal rectal temperatures and respiratory rates. Bos indicus generally have more number of functional, sweat glands per unit area of the skin which helps them to survive under higher temperature. They have highest cutaneous and lowest respiratory heat loss, as such panting is less (Patoo et al., 2016a). Observation in India on crossbred cows has shown that the productivity of crossbred (Holstein-Friesian, Brown Swiss and Jersey with various Indian breeds) was seriously affected by the hot-humid climatic condition (Thomas and Acharya, 1981). Change in physiological responses, such as body temperature, respiration rate, etc. gave us an idea about the adaptability of animals under tropical and subtropical condition. Increased rectal temperatures (an indication of body core 
temperature) as well as respiration and heart rates are usually indications of heat stress. So the present investigation was undertaken to study the effect of season on physiological response and heat tolerance indices of Sahiwal, crossbred and Hill (Badri) cattle under farm condition in foot hills of Uttarakhand.

Present study was conducted at Instructional Dairy Farm (IDF), GBPUAT, Pantnagar, Uttarakhand from October 2011 to December 2012. Maximum temperature reaches up to $44^{\circ} \mathrm{C}$ in summers and minimum temperature up to $1^{\circ} \mathrm{C}$ in winters. Experimental work was conducted on available Sahiwal, crossbred and Hill (Badri) cattle which were selected randomly from the respective herds and maintained in separate groups under loose housing system. Nutritional requirements of animals were met through a balanced combination of dry and green fodder with concentrate mixture supplementation. Crossbred animals were crosses of HolsteinFriesian with Sahiwal while representative Hill (Badri) cattle were brought from Almora district of Uttarakhand and scientifically maintained at the university farm. Meteorological data viz. ambient temperature (dry and wet), relative humidity (minimum and maximum) and rainfall were recorded from Crop Research Center, GBPUAT, Pantnagar for peak 20 days in summer, rainy and winter season were recorded (table 1).

Physiological responses were measured in four primiparious lactating cows of each group by recording daily morning (9 A.M.) and evening (3 P.M.) rectal temperature, respiration rate and pulse rate for peak 20 days in summer, rainy and winter season. Based on above meterological and physilogical data, Temperature Humidity Index (Esmay and Dixon, 1986), Iberia Heat Tolerance Coefficient (Rhoad, 1944), Benezara Coefficient of Adaptability (Benezara, 1954) and Dairy Search Index (Thomas et al., 1973) were calculated by following equations.

$\mathrm{THI}=0.72(\mathrm{Cdb}+\mathrm{Cwb})+40.6$

where $\mathrm{Cdb}$ : Dry bulb temperature $\left({ }^{\circ} \mathrm{C}\right), \mathrm{Cwb}$ : Wet bulb temperature $\left({ }^{\circ} \mathrm{C}\right)$

$\mathrm{IHTC}=100-10(\mathrm{BT}-101)$

where BT: Observed body temperature $\left({ }^{\circ} \mathrm{F}\right)$ of the animal

$\mathrm{BCA}=\mathrm{BT} / 38.33+\mathrm{NR} / 23$ where BT: Rectal temperature $\left({ }^{\circ} \mathrm{C}\right), \mathrm{NR}$ : Respiration rate per minute

$$
\mathrm{DSI}=0.5(\mathrm{X} 1 / \mathrm{X})+0.2(\mathrm{Y} 1 / \mathrm{Y})+0.3(\mathrm{Z1} / \mathrm{Z})
$$

where X1, Y1, and Z1 are the observed RT, RR and PR, X, Y and $Z$ are normal RT, RR and

$$
\mathrm{PR},\left(38.67^{\circ} \mathrm{C}, 30 \mathrm{bpm} \text { and } 70 \text { per minute }\right)
$$

Data obtained in the present study were analyzed statistically and subjected to test of significance as per the methods described by Snedecor and Cochran (1994). $\mathrm{P} \leq 0.05$ were considered to be statistically significant.

There was a significant $(\mathrm{P} \leq 0.05)$ difference between mean morning and evening rectal temperature (RT), respiration (RR) and pulse rate (PR) in Sahiwal/Hill cows and crossbred cows but non-significant difference between Sahiwal and Hill (Badri) cows during summer and rainy season (table 2 ). There was a significant $(\mathrm{P} \leq 0.05)$ difference between summer/rainy and winter season in morning and evening RT, RR and PR in all the groups and a nonsignificant $(\mathrm{P} \geq 0.05)$ difference between summer and rainy season. Mean morning and evening RT, RR and PR were non-significant $(\mathrm{P} \geq 0.05)$ in all the groups during winter season but higher values were observed during evening.Overall morning and evening RT during summer season in Sahiwal, Crossbred and Hill (Badri) cattle were as $101.29 \pm 0.04$ and $101.55 \pm 0.05^{\circ} \mathrm{F}, 101.74 \pm 0.07$ and $102.12 \pm 0.08^{\circ} \mathrm{F}$ and $101.39 \pm 0.08$ and $101.69 \pm 0.06^{\circ} \mathrm{F} ; \mathrm{RR}$ were as $23.05 \pm 0.45$ and $30.04 \pm 0.46$ breaths $/ \mathrm{min}, 29.54 \pm 0.56$ and $49.53 \pm 0.39$ breaths $/ \mathrm{min}$ and $24.22 \pm 0.48$ and $31.06 \pm 0.42$ breaths $/ \mathrm{min}$ and $P R$ were as $58.11 \pm 0.31$ and $61.04 \pm 0.34$ beats $/ \mathrm{min}, 61.14 \pm 0.49$ and $66.68 \pm 0.25$ beats $/ \mathrm{min}$ and $59.04 \pm 0.26$ and $62.11 \pm 0.21$ beats $/ \mathrm{min}$ for Sahiwal, crossbreds and Hill (Badri) cows, respectively. Present findings were in accordance with Bhan et al. (2012) who reported that mean values of RT, RR and PR of growing and adult Sahiwal cows increased significantly $(\mathrm{P}<0.01)$ during afternoon compared to morning values. Abdelatif and Alameen (2012) reported that RT and RR during summer in crossbred dairy cows were significantly $(\mathrm{P}<0.05)$ higher than winter season. Increase in RT and RR during summer was reported by many workers in Holstein Friesian cattle and crossbred cows (Korde et al. 2005; Srivastava et al. 2005a). Madke et al. (2010) reported increase in

\begin{tabular}{|c|c|c|c|c|c|c|c|c|}
\hline Season & \multicolumn{2}{|c|}{$\begin{array}{l}\text { Ambient } \\
\text { Temperature }\left({ }^{\circ} \mathrm{C}\right)\end{array}$} & \multicolumn{2}{|c|}{$\begin{array}{l}\text { Relative } \\
\text { Humidity (\%) }\end{array}$} & $\begin{array}{l}\text { Sunshine } \\
\text { (hrs) }\end{array}$ & $\begin{array}{l}\text { Wind velocity } \\
(\mathrm{Km} / \mathrm{hrs})\end{array}$ & $\begin{array}{l}\text { Rain } \\
(\mathrm{mm})\end{array}$ & THI \\
\hline Summer & $40.89 \pm 0.05$ & $23.08 \pm 0.07$ & $60.00 \pm 0.12$ & $22.70 \pm 0.11$ & $8.94 \pm 0.07$ & $8.44 \pm 0.06$ & $0.0 \pm 0.0$ & $81.13 \pm 0.06$ \\
\hline Winter & $18.32 \pm 0.06$ & $8.15 \pm 0.08$ & $91.10 \pm 0.07$ & $65.85 \pm 0.15$ & $2.87 \pm 0.08$ & $4.16 \pm 0.07$ & $0.0 \pm 0.0$ & $58.48 \pm 0.07$ \\
\hline
\end{tabular}

Table 1 Average $( \pm \mathrm{SE})$ climatic variables and THI during different seasons 
Table 2 Average $( \pm \mathrm{SE})$ physiological parameters in Sahiwal, crossbred and Hill (Badri) cattle during different seasons

\begin{tabular}{|c|c|c|c|c|c|c|c|}
\hline \multirow{2}{*}{ Season } & \multirow{2}{*}{$\begin{array}{l}\text { Physiological } \\
\text { parameters }\end{array}$} & \multicolumn{3}{|l|}{ Morning } & \multicolumn{3}{|l|}{ Evening } \\
\hline & & $\overline{\mathrm{SC}}$ & $\mathrm{CB}$ & $\mathrm{HC}$ & $\mathrm{SC}$ & $\mathrm{CB}$ & $\mathrm{HC}$ \\
\hline \multirow[t]{2}{*}{ Summer } & RT & $101.29 \pm 0.04^{b}$ & $101.74 \pm 0.07^{\mathrm{a}}$ & $101.39 \pm 0.08^{b}$ & $101.55 \pm 0.05^{b}$ & $102.12 \pm 0.08^{\mathrm{a}}$ & $101.69 \pm 0.06^{b}$ \\
\hline & $\mathrm{RR}$ & $23.05 \pm 0.45^{\mathrm{b}}$ & $29.54 \pm 0.56^{\mathrm{a}}$ & $24.22 \pm 0.48^{\mathrm{b}}$ & $30.04 \pm 0.46^{\mathrm{b}}$ & $49.53 \pm 0.39^{\mathrm{a}}$ & $31.06 \pm 0.42^{b}$ \\
\hline \multirow[t]{2}{*}{ Rainy } & RT & $101.21 \pm 0.07^{b}$ & $101.67 \pm 0.08^{\mathrm{a}}$ & $101.31 \pm 0.10^{\mathrm{b}}$ & $101.46 \pm 0.08^{b}$ & $101.98 \pm 0.06^{\mathrm{a}}$ & $101.56 \pm 0.07^{b}$ \\
\hline & $\mathrm{RR}$ & $21.23 \pm 0.48^{\mathrm{b}}$ & $27.94 \pm 0.24^{\mathrm{a}}$ & $22.52 \pm 0.31^{\mathrm{b}}$ & $26.79 \pm 0.42^{b}$ & $36.33 \pm 0.34^{\mathrm{a}}$ & $27.96 \pm 0.38^{b}$ \\
\hline & $\mathrm{RR}$ & $18.30 \pm 0.27$ & $20.26 \pm 0.35$ & $19.34 \pm 0.28$ & $22.25 \pm 0.34$ & $24.58 \pm 0.28$ & $23.17 \pm 0.31$ \\
\hline & PR & $55.39 \pm 0.28$ & $57.40 \pm 0.41$ & $56.02 \pm 0.39$ & $56.33 \pm 0.31$ & $59.00 \pm 0.25$ & $57.07 \pm 0.32$ \\
\hline
\end{tabular}

Values bearing different superscripts in the same rows differ significantly $(\mathrm{P} \leq 0.05)$. No. of observations for each groups were four animals. $\mathrm{SC}=$ Sahiwal, $\mathrm{CB}=$ Crossbred, $\mathrm{HC}=$ Hill (Badri) cattle $\mathrm{RT}=$ Rectal Temperature, $\mathrm{RR}=$ Respiration $\mathrm{Rate} \mathrm{PR}=\mathrm{Pul}$ (se $\mathrm{Rate}$

Table 3 Average $( \pm$ SE) heat tolerance indices in Sahiwal, crossbred and Hill (Badri) cattle during different seasons

\begin{tabular}{llllllllll}
\hline \multirow{2}{*}{ Season } & IHTC & \multicolumn{7}{c}{ BCA } & \multicolumn{3}{c}{ DSI } & CB & \\
\cline { 2 - 9 } & SC & CB & HC & SC & CB & HC & SC & HC \\
\hline Summer & $95.73 \pm 0.41^{\mathrm{a}}$ & $90.67 \pm 0.32^{\mathrm{b}}$ & $94.53 \pm 0.43^{\mathrm{a}}$ & $2.16 \pm 0.09^{\mathrm{b}}$ & $2.73 \pm 0.12^{\mathrm{a}}$ & $2.20 \pm 0.07^{\mathrm{b}}$ & $0.931 \pm 0.02^{\mathrm{b}}$ & $1.039 \pm 0.03^{\mathrm{a}}$ & $0.943 \pm 0.04^{\mathrm{b}}$ \\
Rainy & $96.63 \pm 0.43^{\mathrm{a}}$ & $91.69 \pm 0.26^{\mathrm{b}}$ & $95.57 \pm 0.29^{\mathrm{a}}$ & $2.04 \pm 0.08^{\mathrm{b}}$ & $2.40 \pm 0.07^{\mathrm{a}}$ & $2.10 \pm 0.06^{\mathrm{b}}$ & $0.911 \pm 0.04^{\mathrm{b}}$ & $0.981 \pm 0.03^{\mathrm{a}}$ & $0.922 \pm 0.02^{\mathrm{b}}$ \\
Winter & $98.02 \pm 0.27$ & $97.58 \pm 0.31$ & $97.70 \pm 0.21$ & $1.88 \pm 0.04$ & $1.97 \pm 0.07$ & $1.92 \pm 0.06$ & $0.871 \pm 0.02$ & $0.896 \pm 0.03$ & $0.881 \pm 0.03$ \\
\hline
\end{tabular}

Values bearing different superscripts in the same rows differ significantly $(\mathrm{P} \leq 0.05)$. No. of observations for each groups were four animals. $\mathrm{SC}=$ Sahiwal $\mathrm{CB}=$ Crossbred $\mathrm{HC}=$ Hill (Badri) cattle

RT and RR during hot dry and hot humid seasons as compared to winter season in Karan Fries cows. Narayan et al. (2007) reported that there was a significant difference between morning and evening RT and RR in crossbred cows during summer season. Singh and Singh (2005) reported that there was higher RR and PR in Karan Fries group than Sahiwal group when exposed to direct solar radiation during summer.

Temperature Humidity Index (THI) during summer, rainy and winter study period ranged from 78.90 to $85.67(81.13 \pm 0.06), 77.03$ to $81.85(79.55 \pm 0.05)$ and 55.14 to $62.63(58.48 \pm 0.07)$, being significantly $(\mathrm{P} \leq 0.05)$ highest during summer and lowest during winter. Higher THI values of ambient environment depress physiological activities and adaptability mechanism in crossbred cattle (Nagarcenkar and Tomar, 1977). A THI exceeding 72 indicates that cattle are under heat stress which in turns affects production performance (Ravagnolo et al. 2000). Similar range of THI (78.1 \pm 2.9 to 86.1 \pm 3.1 ) in summer season in Pantnagar region was reported by Narayan (2005). There was a significant $(\mathrm{P} \leq 0.05)$ difference between Iberia heat tolerance coefficient (IHTC), Benezara coefficient of adaptability (BCA) and Dairy search index (DSI) values between crossbred cows and Sahiwal/ Hill cows during summer and rainy season (Table 3). For IHTC maximum values during summer, rainy and winter season were $95.73 \pm 0.41$, $96.63 \pm 0.43$ and $98.02 \pm 0.27$ for Sahiwal and the minimum $90.67 \pm 0.32$, $91.69 \pm 0.26$ and $97.58 \pm 0.31$ for crossbreds, respectively. For BCA maximum values during summer, rainy and winter season were $2.73 \pm 0.12,2.40 \pm 0.07$ and $1.97 \pm 0.07$ for crossbreds and the minimum
$2.16 \pm 0.09,2.04 \pm 0.08$ and $1.88 \pm 0.04$ for Sahiwal cows, respectively. For DSI maximum values during summer, rainy and winter season were as $1.039 \pm 0.03,0.981 \pm 0.03$ and $0.896 \pm 0.03$ for crossbreds and the minimum $0.931 \pm 0.02,0.911 \pm 0.04$ and $0.871 \pm 0.02$ for Sahiwal cows, respectively. These heat tolerance indices indicated that Sahiwal cows were more heat resistant than Hill (Badri) cows and crossbred cows, the least heat resistant during summer and rainy season. Moreover, during winter season none of the groups were under any stress. Das (2012) reported that IHTC and BCA indicated highest thermo adaptability of crossbred calves in the month December in Bihar. Similar value of IHTC, BCA and DSI were observed by Sreedhar et al. (2011) in Sahiwal heifers, cows and Jersey x Sahiwal crossbreds during peak summer season (Kundu and Bhatnagar, 1980).

\section{Conclusions}

Heat tolerance indices and physiological parameters indicated that Sahiwal cows were more heat resistant followed by Hill (Badri) cows and crossbreds in hot humid climatic conditions in foot Hills of Uttarakhand.

\section{Acknowledgments}

The authors express sincere thanks to the Director, Instructional Dairy Farm, GBPUAT, Pantnagar, Uttarakhand, for providing all necessary facilities for conducting research work. 


\section{References}

Abdelatif AM and Alameen AO (2012) Influence of season and pregnancy on thermoregulation and haematological profile in crossbred dairy cows in tropical environment. Global Vetermaria 9(3): 334-340

Benezara MV (1954) A new index for measuring the adaptability of cattle to tropical conditions. J Ani Sci 13: 1015-1022

Bhan C, Singh SV, Hooda OK, Upadhyay RC, Beenam and Mangesh V (2012) Influence of temperature variability on physiological, haematological and biochemical profile of growing and adult Sahiwal cattle. Journal of Environment Research Development 7 (2A): 986 990

Das SK (2012) Effect of THI on Milk Production and Physiological Responses of Crossbred Cows during Different months under the Agro Climatic Condition of Bihar. Indian Journal of Dairy Sciences 65(3) 20-24

Esmay and Dixon (1986) Improvement of livestock production in warm climate. R E. McDowell (Ed.), W.H. Freeman and company, Sanfrancisco. pp. 51-69

Korde JP, Jadhao SV, Shukla DC and Varshney VP (2005) Effect of long term exposure to heat stress on nutrient digestibility and digesta flow rate in buffalo calves. Proceeding of national seminar on Recent advances in cryopreservation of livestock germplasm. Jan 28-29, 2005, Anjora, pp. 304-310

Kundu AK, Bhatnagar DS (1980) Note on heat tolerance in cross-bred cows and its relation with milk yield. Indian Journal of Animal Science 50 (7): 567-569

Madke PK, Lathwal SS, Singh Y, Kumar A, Kaushik V (2010) Study of behavioural and physiological changes of crossbred cows under different shelter management practices. Indian Journal of Animal Science, 80(8): 771-774

Nagarcenkar R, Tomar OS (1977) Management practices for crossbred animals. Indian Dairyman 29: 29-32

Narayan U (2005) Amelioration of summer stress in lactating crossbred cows under farm conditions of Tarai region. Thesis, M. V. Sc. G.B. Pant University of Agriculture and Technology, Pantnagar, Uttarakhand
Narayan U, Singh DV, Sharma RJ (2007) Physiological Responses in Holstein-Friesian Crossbred Lactating Cows Under Heat Stress Ameliorating Treatments. Indian Journal of Animal Research 41(2): 130-133

Patoo RA, Singh DV, Singh SK, Chaudhari BK, Singh AK, Singh MK, Kaushal S (2016a) Comparative study on some morphological and performance traits of Hill cattle, Sahiwal and crossbred cattle. Indian Journal of Animal 50 (2): 148-151

Patoo RA, Singh DV, Singh SK, Singh MK, Singh AK, Kaushal S (2016b) Colostrum and milk composition during postpartum period in Hill cow, Sahiwal and crossbred cow. Indian Journal of Animal 50 (2): 211-214

Pundir RK, Singh PK, Neelkant Sharma D, Singh CV and Prakash B (2013) Uttara-A new cattle germplasm from Uttarakhand hills. Indian Journal of Animal Science 83(1): 51-58

Ravagnolo O, Misztal I, Hoogenboom G (2000) Genetic component of heat stress cattle development of heat index function. Journal of Dairy Science 83: 2120-2125

Rhoad AO (1944) The Iberia heat tolerance test for cattle. Trop Agri 21: $162-170$

Singh R, Singh SV (2005) Variations in cutaneous temperature, physiological responses and blood biochemical in Karan Fries and Sahiwal heifers during solar exposure in summer. Indian Journal of Dairy Science 58(6): 415-419

Snedecor GW, Cochran WG (1994) Statistical Methods. 7th Edn. Iowa State, Univ. Press, Ames, Iowa

Sreedhar S, Sarjan RK, Suresh J, Moorthy PRS, Reddy VP (2011) Thermoadaptability of Sahiwal and Jersey x Sahiwal animals during Tropical Environments. Oral presentation in XVIII Annual Convention of Indian Society of Animal Production and Management, Ludhiana. pp. 45-49

Thomas CK, Sharma, KNS, Georgie GC, Razdan MN (1973) A new heat tolerance index for cattle. Indian Journal of Animal Science, 43(6): 505-510

Thomas CK, Acharya RM (1981) Note on the effect of physical environment on milk production in Bos indicus x Bos taurus crosses. Indian Journal of Animal Science 51(3): 351-356 